\title{
Reviewing Research About the Early Life History of Freshwater Fish in China
}

\author{
Yanfei Huang* \\ Hunan University of Arts and Science, College of Life and Environmental Sciences, China
}

*Corresponding author: Yanfei Huang, Hunan University of Arts and Science,

College of Life and Environmental Sciences, China.

Received Date: Jaunary 15, 2019

Published Date: January 24, 2019

\section{Review}

Recruitment strength is well recognized to be determined in the first year of fish and is closely related with growth and survival rate in the early life history [1]. Numerous studies have attempted to understand recruitment mechanism and predict population dynamics by analyzing occurrence, abundance, growth and mortality rate and its relationship with environmental variables in the larval and juvenile stages [2] Early life history studies have been highly developed since 1914, when Hjort first proposed that variation in larval survival could generate recruitment variability [3] Research contents of early life history can be categorized into three aspects: ontogenetic development and identification, distribution and abundance, and growth and survival. Larval species can be identified by morphological characters and molecular analysis [4] Spatial and temporal changes on larval occurrence and abundance in relation with environmental factors have been widely documented $[5,6]$ Larval dispersal is an important component of understanding distribution and recruitment [7] Spatial and temporal variations on growth and mortality rates and its relationship abiotic and biotic factors are essential for revealing recruitment mechanism [8] In addition, the 'growth-mortality' hypothesis has been verified and implemented in many studies $[9,10]$.

Freshwater resource is very plentiful, characterized with three large rivers and numerous small independent rivers. The Yangtze River, the third longest in the world, has 3000 tributaries and 400 lakes. The Yellow River, the second longest river in China, is located the northernmost in China relatively to the other two rivers. The Pearl River, the third longest river in China, is composed of three main tributaries, with the highest fish biodiversity. A total of 920 fish species were record in Chinese rivers, belonging to 302 genera, 54 families and 21orders [11] The natural catches of freshwater fish raught $161.58 \times 107 \mathrm{~kg}$, which produced an economic value of $¥ 461.75 \times 108$ in 2017 [12] Approximately 378 fish species were found in the Yangtze River, with dozens of economically important fish species [13] 385 fish species were recorded in the Pearl River basin, including 29 economically important fish species [14] 191 fish species were recorded in the Yellow River, with 16 economically important fish species [15] So, fishery resources are very important for food requirement and income of people in China and studying early life history of fish is fundamental for keeping sustainable fishery resources.

Identifying species of larvae is very difficult and elaborate work as a few distinguishing characteristics in the larval stage. Describing early development and morphological characteristics through breeding fish was started from 1950s in China. Ontogenetic development of four major Chinese carp species was firstly described, and then other economically important fish successively were undertaken [16] Now, early development and distinguishing characteristics have been known for many common fish species. Some books about identifying species and investigating fishery resources at early life history have been published. For unbreedable or rare or species, which cannot identify through morphological characters, molecular methods have been used in some researches $[17,18]$ Molecular method improves accuracy of identifying larval species, but it is expensive and cannot be used to analyze many specimens. So molecular method should be together with morphological identification is used to identify larval species [19] Based on this data, the temporal and spatial patterns of larval fish assemblages can be analyzed and the relationship between larval abundance with environmental factors is erected. Many investigations about larval diversity and occurrence have been widely undertaken in different habitats in mainstreams, tributaries and lakes in China [20-22] These studies suggest that larval assemblages have been changed due to intense anthropogenic activities. The Chinese rivers have heavily dammed and the ecological integrity of a river ecosystem has been disrupted [23] 
The natural flow regime has been regulated by hydropower, and consequently the dispersal and survival of drifting eggs and larvae have been influenced. But now the dispersal process of larvae has seldom studied in China.

Otolith microstructure is an important method for analyzing early life history traits by revealing daily ages, hatch date and increment width of larvae [11]. Otolith microstructure records early life events and stage durations of fishes, such as, the first feeding, the metamorphosis, settlement, and so on [14,19] Using otolith microstructure, the variations on growth and mortality rate among cohorts hatched in different dates, months and years and come from discrete spawning grounds can be compared in relation with environmental conditions. The relationship between growth rate, environmental variables and recruitment can be erected to reveal population dynamics [1,2] The development and characteristics of otolith in the early life history have been largely described for many fish species. And daily increments have been verified in the otoliths of diverse fish species, the first daily increment are deposited at hatching, or one day after hatching or the first feeding $[7,12]$ However, in China, growth and mortality rates have rarely analyzed for larvae in the natural rivers. Studies about the relationship between growth rate and recruitment are very limited. The recruitment processes of economically important fish species have been little understood [14]. The knowledge about growth, mortality rate and recruitment in China obviously lag international level.

Fish diversity has decreased and fishery resources have heavily declined in rivers, streams and lakes in China [23] Early life history research is relatively undeveloped, and not enough to match with the urgent fishery management and conservation in China. Studies about early life history especially about growth and mortality rate should be the focus of fish ecology in the future in China.

\section{Acknowledgment}

None.

\section{Conflict of Interest}

No conflict of interest.

\section{References}

1. Aldanondo N, Cotano U, Goikoetxea N, Boyra G, Ibaibarriaga L, et al. (2016) Interannual differences in growth and hatch-date distributions of early juvenile European anchovy in the Bay of Biscay: implications for recruitment. Fisheries Oceanography 25(2): 147-163.

2. Gao L, Cheng F, Song Y, Jiang W, Feng G, et al. (2018) Patterns of larval fish assemblages along the direction of freshwater input within the southern branch of the Yangtze Estuary, China: implications for conservation. Journal of Freshwater Ecology 33: 97-114.

3. Fu C Z, JH Wu, JK Chen, QH Wu, GC Lei (2003) Freshwater fish biodiversity in the yangtze river basin of china: patterns, threats and conservation. Biodiversity and Conservation 12(8): 1649-1685.

4. Xiao ZM, Guo XZ (2008) The progress on early life history stages research of fish. Aquaculture of Beijing 110: 42-45.

5. Lechner A, Keckeis H, Glas M, Tritthart M, Habersack H, et al. (2018) The influence of discharge, current speed, and development on the downstream dispersal of larval nase (Chondrostoma nasus) in the River Danube. Canadian Journal of Fisheries and Aquatic Sciences 75: $247-$ 259.

6. Huang Y, Chen F, Tang W, Lai Z, Li X (2017) Validation of daily increment deposition and early growth of mud carp Cirrhinus molitorella. Journal of Fish Biology 90(4): 1517-1532.

7. Huang Y, Li X, Zhu S, Wu Z (2018) Identification of two hatch datedependent cohorts and variation in early growth rate of mud carp (Cirrhinus molitorella) in the Pearl River Delta, China. Marine and Freshwater Research 69: 1231-1237.

8. Beveren EV, Klein M, Serrão EA, Gonçalves EJ, Borges R (2016) Early life history of larvae and early juvenile Atlantic horse mackerel Trachurus trachurus off the Portuguese west coast. Fisheries Research 183: 111118.

9. Miller BS, Kendall AW (2009) Early life history of Marine Fishes. University of California Press, California, USA, p.376.

10. Meulenbroek P, Drexler S, Huemer D, Gruber S, Krumböck S, et al. (2018) Species-specific fish larvae drift in anthropogenically constructed riparian zones on the Vienna impoundment of the River Danube, Austria: Species occurrence, frequencies, and seasonal patterns based on DNA barcoding. River Research and Applications 34(7): 854-862.

11. Green BS, Mapstone BD, Carlos G (2009) Tropical fish otoliths: Information for assessment, management and ecology, reviews: methods and technologies in fish biology and fisheries. Springer, Tokyo p.313.

12. Fishery and Fishery Administration Authority of China Agriculture (2018) China Fishery Statistical Yearbook. China Agriculture Press: Beijing.

13. Kang B, Deng J, Wu Y, Chen L, Zhang J, et al. (2014) Mapping China's freshwater fishes: diversity and biogeography. Fish and Fisheries 15(2): 209-230.

14. Cheng F, Li W, Klopfer M, Murphy BR, Xie S (2015) Population genetic structure and its implication for conservation of coreius guichenoti in the upper Yangtze River. Environmental Biology of Fishes 98(9): 19992007.

15. Cooperation Team of Survey on Fishery Resources of the Yellow River System (1986) Fishery Resources in the Yellow River System. Liaoning Science and Technology Publishing House, Shenyang, China p.160.

16. Ding C, Chen Y, He D, Tao J (2015) Validation of daily increment formation in otoliths for Gymnocypris selincuoensis in the Tibetan Plateau, China. Ecology and Evolution 5(16): 3243-3249.

17. Meulenbroek P, Drexler S, Huemer D, Gruber S, Krumböck S, et al. (2018) Species-specific fish larvae drift in anthropogenically constructed riparian zones on the Vienna impoundment of the River Danube, Austria: Species occurrence, frequencies, and seasonal patterns based on DNA barcoding. River Research and Applications 34(7): 854-862.

18. Basilone G, Ferreri R, Mangano S, Pulizzi M, Gargano A, et al. (2018) Effects of habitat conditions at hatching time on growth history of offspring European anchovy, Engraulis encrasicolus, in the Central Mediterranean Sea. Hydrobiologia 821(1): 99-111.

19. Lu K (1990) Fishery resources investigation in the Pearl River. Guangzhou NY: Guangdong Province Science Publication.

20. Fuiman LA, Werner RG (2002) Fishery science: the unique contributions of early life stages. p. 340

21. Ren P, He H, Song Y, Cheng F, Xie S (2015) The spatial pattern of larval fish assemblages in the lower reach of the Yangtze River: potential influences of river-lake connectivity and tidal intrusion. Hydrobiologia 766(1): 365-379.

22. Shuai F, Li X, Liu Q Li Y, Yang J, et al. (2017) Temporal patterns of fish diversity and distribution in the Pearl River. Acta Ecologica Sinica 37: 3182-3192.

23. Song Z, Fu Z, Li J, Yue B (2008) Validation of daily otolith increments in larval and juvenile Chinese sucker, Myxocyprinus asiaticus. Environmental Biology of Fishes 82: 165-171. 